\title{
Pengaruh Harga, Promosi Dan Saluran Distribusi Semen Gresik Terhadap Minat Beli Konsumen (Studi Kasus di Distributor PT Abadi Putera Wirajaya)
}

\author{
Widya Purnamasari ${ }^{1}$, Ahadiati Rohmatiah ${ }^{2}$, Mintarti Indartini ${ }^{3}$ \\ ${ }^{1}$ Program Studi Manajemen, Universitas Merdeka Madiun, Jl Serayu 70, Kota Madiun, 63133 \\ Email: widyapurnamasari15@gmail.com \\ ${ }^{2}$ Program Studi Manajemen, Universitas Merdeka Madiun, Jl Serayu 70, Kota Madiun, 63133 \\ Email: ahadiati@unmer-madiunac.id \\ ${ }^{3}$ Program Studi Manajemen, Universitas Merdeka Madiun, Jl Serayu 70, Kota Madiun, 63133 \\ Email: mintartiindartini@unmer-madiun.ac.id
}

\begin{abstract}
The existence of PT Abadi Putera Wirajaya Karesidenan Madiun as a distributor must be used as the spearhead of the marketing of Semen Gresik products by increasing consumer buying interest. This study aims to determine the partially and simultaneously influence of price, promotion and distribution channels on consumer buying interest in Semen Gresik products at distributor of PT Abadi Putera Wirajaya Karesidenan Madiun and the variables that have a dominant influence on consumer buying interest in this products at distributor of PT Abadi Putera Wirajaya Karesidenan Madiun. The population in this study were all distributor channels in PT Abadi Putera Wirajaya Karesidenan Madiun in 2020, totaling 137 distributors. The sample in this study was 102 distributors whose size was determined by the Slovin formula. Sampling using random sampling technique. The research instrument used a questionnaire. The data analysis technique used validity and reliability test, classical assumption test, coefficient of determination analysis and hypothesis testing using $t$ test, $F$ test and standardized coefficients test. The results of the study are: 1) Price, promotion and distribution channels variables partially influences consumer buying interest in Semen Gresik products at distributor of PT Abadi Putera Wirajaya Karesidenan Madiun, 2) Price, promotion and distribution channels variables simultaneously influences consumer buying interest in Semen Gresik products at distributor of PT Abadi Putera Wirajaya Karesidenan Madiun, 3) Promotion is a variable that has a dominant influence on consumer buying interest in Semen Gresik products at distributor of PT Abadi Putera Wirajaya Karesidenan Madiun.
\end{abstract}

Keywords—: Price; Promotion; Distribution Channels; Buying Interes.

\section{PENDAHULUAN}

Menurut data ASI (2019), selama tahun 2015-2019 kebutuhan produk semen mengalami pertumbuhan yang fluktuatif, seperti yang digambarkan pada grafik konsumsi semen berikut ini:

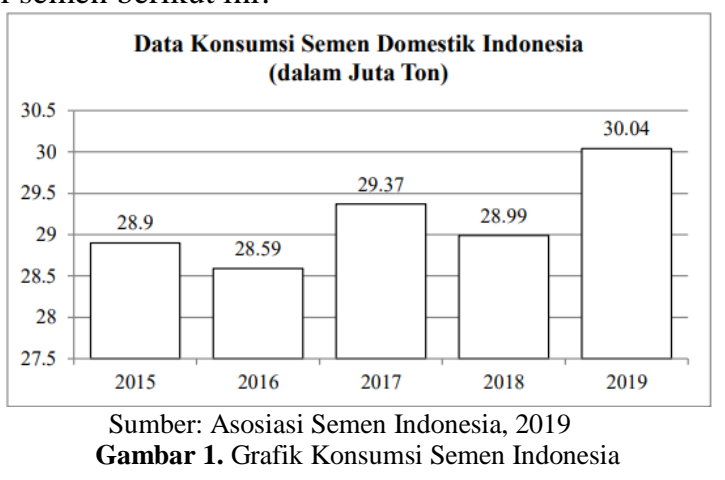

Industri semen di Indonesia terus mengalami perkembangan, pada Gambar 1 terlihat tingkat konsumsi semen domestik selama periode 5 tahun terakhir (first half) dari tahun 2015-2019 mengalami pertumbuhan yang fluktuatif. Pada tahun 2015 tingkat konsumsi semen domestik sebesar 28,9 juta ton kemudian turun menjadi 28,59 juta ton di tahun 2016 . Terjadi peningkatan kembali di tahun 2017 menjadi 29,37 juta ton namun kembali turun ke angka 28,99 juta ton di tahun 2018. Selama periode tahun 2019 terjadi peningkatan volume sekitar 1 juta ton menjadi 30,04 juta ton dibandingkan tahun sebelumnya di tahun 2018. 
Tingginya tingkat kebutuhan semen di Indonesia telah mendorong terjadinya persaingan diantara perusahaan-perusahaan besar dalam memproduksi semen. Selama ini, Semen Gresik merupakan market leader di pasar Jawa Timur dengan pangsa pasar lebih dari 70\%. Berkaitan dengan adanya persaingan pasar, maka untuk mempertahankan posisinya maka PT Semen Indonesia, Tbk. yang memproduksi Semen Gresik perlu menerapkan strategi pemasaran yang tepat untuk menghadapi persaingan. Aktivitas pemasaran memegang peranan yang sangat penting dalam pemasaran produk semen, sehingga PT Semen Indonesia, Tbk. telah mengarahkan setiap perusahaan distributor untuk mendukung aktivitas pemasaran yang relevan dengan kondisi persaingan yang terjadi di pasar. Salah satu perusahaan distributor produk dari PT Semen Indonesia, Tbk. adalah PT Abadi Putera Wirajaya Madiun, yang merupakan distributor untuk produk Semen Gresik.

Salah satu upaya yang dapat dilakukan suatu pemasar dalam memenangkan persaingan pasar adalah dengan meningkatkan minat pembelian pada konsumen. Keberadaan minat pembelian tidak terlepas dari perilaku konsumen dalam merespon positif terhadap hal-hal yang telah disampaikan para pemasar dan berminat untuk melakukan pembelian suatu produk. Hal ini seperti yang disampaikan Kotler \& Keller (2016) bahwa minat beli konsumen adalah sebuah perilaku konsumen dimana konsumen mempunyai keinginan dalam membeli atau memilih suatu produk, berdasarkan pengalaman dalam memilih, menggunakan dan mengkonsumsi atau bahkan menginginkan suatu produk. Pada konsumen yang mempunyai minat untuk membeli suatu produk menunjukkan adanya perhatian dan rasa senang terhadap produk untuk kemudian minat membeli tersebut akan diikuti dengan realisasi yang berupa perilaku membeli. Keberadaan minat pembelian pada konsumen tidak terlepas dari kemampuan perusahaan dalam mengetahui perilaku konsumen. Pada kebanyakan orang, perilaku pembelian konsumen seringkali diawali dan dipengaruhi oleh banyaknya rangsangan atau stimulus dari luar dirinya. Beberapa faktor yang diduga dapat menjadi stimulus seorang konsumen berminat untuk melakukan pembelian terhadap suatu produk adalah harga dan promosi yang diterapkan pemasar serta saluran distribusi yang digunakan pemasar untuk menjual produk di pasar. Hal ini seperti yang disampaikan Mahmoud (2018) dalam penelitiannya yang membuktikan bahwa faktor-faktor marketing mix yang berpengaruh terhadap purchase intention meliputi produk (product), price (harga), place (tempat distribusi) dan promotion (promosi). Namun, pada penelitian ini faktor-faktor marketing mix hanya dibatasi pada harga, promosi dan distribusi karena sesuai dengan karakteristik dari produk, maka pada produk semen memiliki sifat dan karakteristik yang hampir sama yaitu sama-sama sebagai material yang akan digunakan sebagai komponen dalam pekerjaan konstruksi.

Menurut Alma (2013) harga adalah sejumlah uang yang dibayarkan atas jasa atau jumlah nilai yang konsumen tukar dalam rangka mendapatkan manfaat dari memiliki atau menggunakan barang atau jasa. Ketepatan PT Semen Indonesia, Tbk. dalam menetapkan harga, khususnya harga eceran tertinggi, yang ditindaklanjuti PT Abadi Putera Wirajaya Madiun sebagai distributor produk Semen Gresik dalam menetapkan harga semen yang dijual langsung kepada konsumen, akan membuat minat beli konsumen meningkat. Penetapan harga semen yang sesuai dengan keinginan konsumen, akan menjadi rangsangan atau stimulus bagi konsumen untuk berminat melakukan pembelian semen di PT Abadi Putera Wirajaya Madiun.

Minat pembelian produk semen yang ada pada konsumen, khususnya pada merek Semen Gresik di PT Abadi Putera Wirajaya Madiun, juga dapat dipengaruhi oleh faktor promosi. Hal ini seperti yang disampaikan Hastono \& Triyadi (2020). yang membuktikan bahwa promosi berpengaruh signifikan terhadap minat konsumen handphone merek Vivo di wilayah Tangerang Selatan. Promosi merupakan salah satu cara bagi PT Semen Indonesia, Tbk. dan PT Abadi Putera Wirajaya Madiun dalam memperkenalkan produk Semen Gresik. Promosi ini dapat dilakukan dengan berbagai cara, baik cetak maupun elektronik. Apabila PT Semen Indonesia, Tbk. dan PT Abadi Putera Wirajaya Madiun mampu memilih strategi promosi penjualan dengan media promosi yang tepat, akan membuat produk Semen Gresik semakin dikenal konsumen. Apabila konsumen telah mengenal dengan baik produk Semen Gresik, maka akan mendorong konsumen untuk tertarik membeli produk Semen Gresik tersebut.

Keberhasil PT Semen Indonesia, Tbk. dalam meningkatkan minat pembelian konsumen terhadap produk Semen Gresik juga tidak terlepas dari keberhasilan perusahaan dalam menentukan saluran distribusi yang digunakan dalam menjual produk. PT Abadi Putera Wirajaya Madiun merupakan salah satu distributor dari PT Semen Indonesia, Tbk. dan sebagai salah satu saluran pemasaran atau distribusi dalam penjualan produk Semen Gresik kepada konsumen. Menurut Walters dalam Saleh \& Said, (2019), saluran distribusi adalah sekelompok pedagang dan agen perusahaan yang mengkombinasikan antara pemindahan fisik dan nama dari suatu produk untuk menciptakan kegunaan bagi pasat tertentu. Saluran distribusi merupakan saluran yang digunakan produsen untuk menyalurkan barang yang diproduksinya agar sampai ke konsumen. Ketepatan dalam memilih saluran distribusi akan menentukan keberhasilan dan kegagalan usaha di masa yang akan datang. Apabila distribusi produk ke pasar sangat lancar, maka produk akan mudah dijangkau dan tersedia bagi pasar sasaran. Keberadaan PT Abadi Putera Wirajaya Madiun sebagai salah satu distributor dari produk Semen Gresik serta toko-toko dari sub-distributor akan membantu pendistribusian produk Semen Gresik ke masyarakat sebagai konsumen dengan tepat sasaran. Apabila konsumen dapat menjangkau keberadaan produk dengan mudah serta ketersedian produk di pasar sangat mudah ditemukan, konsumen akan memiliki minat pembelian yang tinggi terhadap produk.

Berdasarkan realita yang ada menunjukkan bahwa PT Semen Indonesia, Tbk. sebagai produsen Semen Gresik harus mampu bersaing dengan produsen semen lain yang memproduksi berbagai merek semen. Adanya gambaran yang menunjukkan bahwa konsumsi produk semen untuk pasar domestik yang masih fluktuatif, maka PT Semen Indonesia, Tbk. harus mampu menerapkan strategi pemasaran yang tepat dalam rangka meningkatkan minat pembelian pada konsumen. Keberadaan PT Abadi Putera Wirajaya Madiun sebagai salah satu distributor Semen Gresik harus dapat dimanfaatkan sebagai ujung tombak 
Website : http://ekomaks.unmermadiun.ac.id/index.php/ekomaks

pemasaran perusahaan yang dapat mendukung upaya-upaya peningkatan minat pembelian konsumen melalui strategi penetapan harga produk, promosi, dan distribusi produk.

\section{Rumusan Masalah}

1. Apakah harga pada produk Semen Gresik berpengaruh terhadap minat beli konsumen di distributor PT Abadi Putera Wirajaya Karesidenan Madiun?

2. Apakah promosi produk Semen Gresik berpengaruh terhadap minat beli konsumen pada distributor PT Abadi Putera Wirajaya Karesidenan Madiun?

3. Apakah saluran distribusi produk Semen Gresik berpengaruh terhadap minat beli konsumen di distributor PT Abadi Putera Wirajaya Karesidenan Madiun?

4. Apakah harga, promosi dan saluran distribusi secara simultan berpengaruh terhadap minat beli konsumen pada produk Semen Gresik di distributor PT Abadi Putera Wirajaya Karesidenan Madiun?

5. Apakah diantara variabel harga, promosi dan saluran distribusi ada yang berpengaruh dominan terhadap minat beli konsumen pada produk Semen Gresik di distributor PT Abadi Putera Wirajaya Karesidenan Madiun?

\section{TINJAUAN TEORITIS}

\section{A. Harga}

Menurut Kotler \& Amstrong (2016), harga adalah the amount of money charged for a ptoduct or service, the sum of the values that customers exchange for the benefit of having or using the product or service. Dengan kata lain, harga yang dimaksud adalah harga yang telah ditetapkan oleh pemasar atau penjual. Persepsi mengenai harga ini dapat bernilai negatif atau positif. Jika konsumen memiliki kesan positif terhadap harga yang ditawarkan perusahaan maka hal tersebut akan menghasilkan persepsi positif, begitu juga sebaliknya. Sehingga hal ini dapat mempengaruhi minat beli masyarakat. Keterkaitan harga dan minat beli ini sesuai dengan hasil penelitian Ati, dkk (2020).

\section{B. Promosi}

Menurut Kotler \& Amstrong (2014:77), promotion refers to activities that communicate the marits of the product and persuade target customers to buy it. Promosi (promotion) menurut Lupiyoadi \& Hamdani (2013) merupakan kegiatan yang dilakukan perusahaan untuk mengkomunikasikan manfaat produk dan sebagai alat untuk mempengaruhi konsumen dalam kegiatan pembelian atau penggunaan jasa sesuai dengan kebutuhan. Sehingga orang yang dipengaruhi ini tertarik terhadap produk yang disampaikan dan akhirnya melakukan pembelian. Hal ini sesuai dengan hasil penelitian Hastono \& Triyadi (2020).

\section{Saluran Distribusi}

Menurut Suparyanto \& Rosad (2015), saluran distribusi adalah semua organisasi yang saling terkait dalam penyampaian produk dari produsen sampai dapat dikonsumsi oleh konsumen akhir. Penyaluran produk ini dapat mempermudah konsumen dalam mendapatkan produk tersebut dan mempermudah perusahaan untuk dapat dikenal dan dimanfaatkan oleh masyarakat. Kemudahan akses dalam mendapatkan suatu produk akan dapat menarik masyarakat untuk melakukan pembeli produk tersebut. Ini berkaitan dengan hasil penelitian dari Sukma, Hermina, \& Novan (2020)

\section{Minat Beli}

Tjiptono (2015) menyatakan bahwa minat beli konsumen mencerminkan hasrat dan keinginan konsumen untuk membeli suatu produk. Menurut Kotler \& Keller (2016), seberapa besar kemungkinan konsumen membeli suatu merek dan jasa atau seberapa besar kemungkinan konsumen untuk berpindah dari satu merek ke merek lainnya. Bila manfaat yang lebih besar dibandingkan pengorbanan untuk mendapatkannya maka dorongan untuk membeli semakin tinggi.

\section{Kerangka Pemikiran}

Berikut gambar kerangka pemikiran dari penelitian ini sehingga membentuk hipotesis:

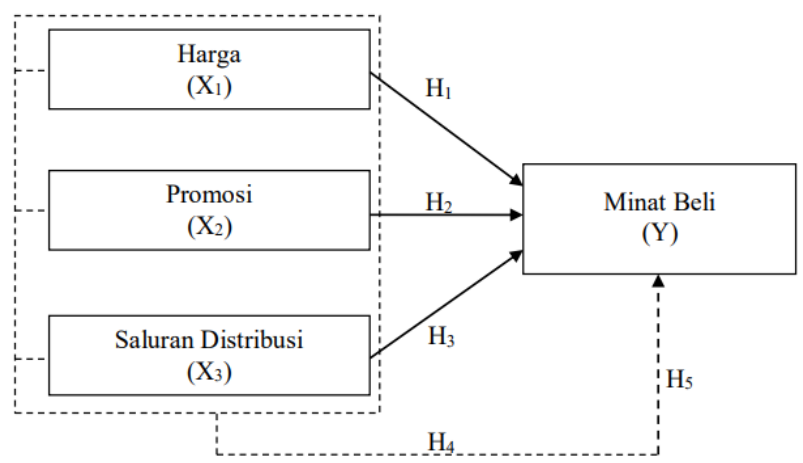

Gambar 2. Kerangka Pemikiran 
Website : http://ekomaks.unmermadiun.ac.id/index.php/ekomaks

Keterangan:

$\longrightarrow$ : Pengaruh secara parsial

$\ldots \ldots$ : Pengaruh secara simultan

Berdasarkan rumusan masalah dan penelitian terdahulu, maka hipotesis dalam penelitian ini adalah sebagai berikut:

1. Harga pada produk Semen Gresik berpengaruh terhadap minat beli konsumen distributor PT Abadi Putera Wirajaya Karesidenan Madiun

2. Promosi produk Semen Gresik berpengaruh terhadap minat beli konsumen distributor PT Abadi Putera Wirajaya Karesidenan Madiun

3. Saluran distribusi produk Semen Gresik berpengaruh terhadap minat beli konsumen pada distributor PT Abadi Putera Wirajaya Karesidenan Madiun

4. Harga, promosi dan saluran distribusi secara simultan berpengaruh terhadap minat beli konsumen pada produk Semen Gresik di distributor PT Abadi Putera Wirajaya Karesidenan Madiun

5. Diantara variabel harga, promosi dan saluran distribusi ada yang berpengaruh dominan terhadap minat beli konsumen pada produk Semen Gresik di distributor PT Abadi Putera Wirajaya Karesidenan Madiun.

\section{III.METODE PENELITIAN}

\section{A. Populasi dan Sampel}

Populasi dalam penelitian ini adalah seluruh saluran distribusi Semen Gresik dari PT Abadi Putera Wirajaya Karesidenan Madiun yang meliputi toko dan distributor. Jumlah toko dan distributor Semen Gresik untuk wilayah Karesidenan Madiun sampai pada bulan Desember 2020 sebanyak 137 distributor. Sehingga dengan menggunakan rumus Slovin, didapat jumlah sampel sebanyak 102 saluran distribusi. Teknik sampling yang digunakan adalah simple random sampling.

\section{B. Indikator Penelitian}

1 Harga (X1)

Menurut Kotler \& Amstrong (2016), terdapat beberapa indikator harga yang dapat digunakan untuk menilai persepsi harga:

a. Keterjangkauan harga

Konsumen bisa menjangkau harga yang telah ditetapkan oleh perusahaan. Produk biasanya ada beberapa jenis dalam satu merek harganya juga berbeda dari yang termurah sampai termahal.

b. Kesesuaian harga dengan kualitas produk

Harga sering dijadikan sebagai indikator kualitas bagi konsumen. Mereka sering memilih harga yang lebih tinggi diantara dua barang karena mereka melihat adanya perbedaan kualitas. Apabila harga lebih tinggi orang cenderung beranggapan bahwa kualitasnya juga lebih baik

c. Kesesuaian harga dengan manfaat

Konsumen memutuskan membeli suatu produk jika manfaat yang dirasakan lebih besar atau sama dengan yang telah dikeluarkan untuk mendapatkannya. Jika konsumen merasakan manfaat produk lebih kecil dari uang yang dikeluarkan maka konsumen akan beranggapan bahwa produk tersebut mahal dan konsumen akan berpikir dua kali untuk melakukan pembelian ulang.

d. Harga sesuai kemampuan atau daya saing harga

Konsumen sering membandingkan harga suatu produk dengan produk lainnya. Dalam hal ini mahal murahnya suatu produk sangat dipertimbangkan oleh konsumen pada saat akan membeli produk tersebut.

2 Promosi (X2)

Menurut Lupiyoadi \& Hamdani (2013) dalam bauran promosi terdapat beberapa komponen yang secara rinci dapat dijabarkan sebagai berikut:

a. Periklanan (Advertising)

Periklanan merupakan suatu bentuk dari komunikasi impersonal yang digunakan oleh perusahaan untuk membangun kesadaran terhadap keberadaan jasa yang ditawarkan, menambah pengetahuan konsumen akan jasa yang ditawarkan serta membedakan diri perusahaan dengan para kompetitornya.

b. Penjualan personal (Personal Selling)

Penjualan personal merupakan suatu bentuk interaksi langsung dengan suatu calon pembeli atau lebih untuk melakukan persentasi, menjawab pertanyaan, dan menerima pesan dari satu calon pembeli.

c. Promosi penjualan (Sales Promotion)

Promosi penjualan adalah kegiatan promosi selain periklanan, penjualan perorangan maupun publisitas yang bersifat jangka pendek dan tidak dilakukan secara berulang serta tidak rutin, yang ditujukan untuk mendorong penjualan, serta lebih mempercepat respon pasar yang ditargetkan.

d. Informasi dari mulut ke mulut (Word of Mouth) 
Website : http://ekomaks.unmermadiun.ac.id/index.php/ekomaks

Dalam hal promosi jasa, peranan orang sangat penting. Pelanggan dekat dengan penyampaian pesan, dengan kata lain pelanggan tersebut akan berbicara kepada pelanggan lain yang berpotensial tentang pengalamannya dalam menerima jasa tersebut.

e. Pemasaran Langsung (Direct Marketing)

Pemasaran ini merupakan unsur terakhir dalam bauran komunikasi promosi ada enam area pemasaran langsung direct mail, mail order, direct response, direct selling, telemarketing, digital marketing.

3 Saluran Distribusi (X3)

Indikator saluran distribusi menurut Keegan dalam Saleh \& Said (2019) meliputi:

a. Tempat, yaitu ketersediaan produk atau jasa di suatu lokasi yang nyaman bagi pelanggan potensial.

b. Waktu, yaitu ketersediaan produk atau jasa yang diinginkan oleh seorang pelanggan.

c. Bentuk, yaitu produk diproses, disiapkan dan siap dimanfaatkan serta dalam kondisi yang tepat.

d. Informasi, yaitu jawaban atas pertanyaan dan komunikasi umum mengenai sifat-sifat produk yang berguna serta manfaat yang tersedia.

4 Minat Beli $(Y)$

Menurut Kotler \& Keller (2016), minat pembelian dapat diidentifikasi melalui indikator-indikator sebagai berikut:

a. Minat transaksional, yaitu kecenderungan seseorang untuk membeli produk.

b. Minat referensial, yaitu kecenderungan seseorang untuk mereferensikan produk kepada orang lain.

c. Minat preferensial, yaitu minat yang menggambarkan perilaku seseorang yang memiliki prefrensi utama pada produk tersebut. Preferensi ini hanya dapat diganti jika terjadi sesuatu dengan produk prefrensinya.

d. Minat eksploratif, minat ini menggambarkan perilaku seseorang yang selalu mencari informasi mengenai produk yang diminatinya dan mencari informasi untuk mendukung sifat-sifat positif dari produk tersebut.

\section{Uji Validitas dan Reliabilitas}

Uji validitas dan reliabilitas dilakukan untuk menguji instrument penelitian sebelum dilanjutkan ke uji asumsi klasik. Ini dilakukan agar dapat diketahui bahwa instrument yang digunakan valid ataukah tidak. Uji validitas dilakukan menggunakan analisis korelasi pearson product moment. Dengan kriteria penilaian "jika $\mathrm{r}$ hitung lebih besar dari $\mathrm{r}$ table, maka butir pertanyaan/pernyataan dikatakan valid" dengan taraf signifikansi 5\% $(0,05)$. Sedangkan uji reliablitas dilakukan dengan melihat koefisien Cronbach's Alpha. Kriteria penilaian uji reliabilitas adalah "jika nilai cronbach's alpha lebih besar dari 0,70 maka instrumen tersebut dikatakan reliabel".

Instrumen penelitian menggunakan skala Likert yang terdiri dari "Sangat Setuju" skor 5, "Setuju" skor 4, "Netral" skor 3, "Tidak Setuju" skor 2, dan "Sangat tidak Setuju” skor 1.

\section{Uji Asumsi Klasik}

Uji asumsi klasik pada penelitian ini terdiri dari uji normalitas data, uji multikolinieritas, dan uji heterokedastisitas. Uji normalitas data menggunakan uji Kolmogorov-Smirnov dengan bantuan SPSS release 22. Uji multikolinieritas dilakukan dengan melihat nilai Tolerance dan Variance Inflation Factor (VIF). Sedangkan uji heterokedastisitas menggunakan scatterplot untuk bisa mendeteksi ada atau tidaknya heterokedastisitas.

\section{E. Koefisien Determinasi}

Menurut Ghozali (2016), koefisien determinasi pada intinya mengukur seberapa jauh kemampuan model dalam menerangkan variasi variabel terikat. Nilai koefisien determinasi yang kecil berarti kemampuan variabel-variabel bebas dalam menjelaskan variasi variabel terikat amat terbatas. Penentuan nilai koefisien determinasi dinyatakan dengan nilai Adjusted $R$ Square.

\section{F. Uji Hipotesis}

Untuk membuktikan hipotesis penelitian, dilakukan uji t dan uji F dengan taraf signifikansi 5\% $(0,05)$.

\section{IV.ANALISIS DAN PEMBAHASAN}

\section{A. Hasil Uji Validitas dan Reliabilitas}

\section{Hasil Uji Validitas}

Berikut tabel rangkuman hasil uji validitas instrument:

Tabel 1. Hasil Uji Validitas Variabel Harga $\left(\mathrm{X}_{1}\right)$, Promosi $\left(\mathrm{X}_{2}\right)$, Saluran Distribusi $\left(\mathrm{X}_{3}\right)$, dan Minat Beli $(\mathrm{Y})$

\begin{tabular}{|c|c|c|c|c|}
\hline Variabel & Item Variabel & Nilai $\mathbf{r}$ hitung & Nilai r tabel $(\mathbf{0 , 1 9 5 6})$ & Keterangan \\
\hline \multirow{4}{*}{ Harga $\left(X_{1}\right)$} & $X_{1} \cdot 1$ & 0,690 & $r$ hitung $>r$ tabel & Valid \\
\cline { 2 - 5 } & $X_{1} \cdot 2$ & 0,600 & $r$ hitung $>r$ tabel & Valid \\
\cline { 2 - 5 } & $X_{1} \cdot 3$ & 0,401 & $r$ hitung $>r$ tabel & Valid \\
\cline { 2 - 5 } & $X_{1} \cdot 4$ & 0,529 & r hitung $>r$ tabel & Valid \\
\hline
\end{tabular}


Website : http://ekomaks.unmermadiun.ac.id/index.php/ekomaks

\begin{tabular}{|c|c|c|c|c|}
\hline & $X_{1} .5$ & 0,619 & $r$ hitung $>r$ tabel & Valid \\
\hline & $X_{1} .6$ & 0,609 & $r$ hitung $>r$ tabel & Valid \\
\hline & $\mathrm{X}_{1} .7$ & 0,659 & $\mathrm{r}$ hitung $>\mathrm{r}$ tabel & Valid \\
\hline & $\mathrm{X}_{1} .8$ & 0,721 & $r$ hitung $>r$ tabel & Valid \\
\hline \multirow{10}{*}{ Promosi $\left(\mathrm{X}_{2}\right)$} & $\overline{X_{2} .1}$ & 0,624 & $r$ hitung $>r$ tabel & Valid \\
\hline & $\mathrm{X}_{2} .2$ & 0,720 & $\mathrm{r}$ hitung $>\mathrm{r}$ tabel & Valid \\
\hline & $X_{2.3}$ & 0,560 & $\mathrm{r}$ hitung $>\mathrm{r}$ tabel & Valid \\
\hline & $\mathrm{X}_{2} .4$ & 0,735 & r hitung $>r$ tabel & Valid \\
\hline & $X_{2} .5$ & 0,716 & $\mathrm{r}$ hitung $>\mathrm{r}$ tabel & Valid \\
\hline & $X_{2} .6$ & 0,737 & $r$ hitung $>r$ tabel & Valid \\
\hline & $\mathrm{X}_{2} .7$ & 0,698 & $\mathrm{r}$ hitung $>\mathrm{r}$ tabel & Valid \\
\hline & $\mathrm{X}_{2} .8$ & 0,721 & $\mathrm{r}$ hitung $>\mathrm{r}$ tabel & Valid \\
\hline & $\mathrm{X}_{2} .9$ & 0,592 & $r$ hitung $>r$ tabel & Valid \\
\hline & $\mathrm{X}_{2.10}$ & 0,627 & $\mathrm{r}$ hitung $>\mathrm{r}$ tabel & Valid \\
\hline \multicolumn{5}{|l|}{ Lanjutan } \\
\hline Variabel & Item Variabel & Nilai r hitung & Nilai $r$ tabel $(0,1956)$ & Keterangan \\
\hline \multirow{8}{*}{$\begin{array}{l}\text { Saluran Distribusi } \\
\left(\mathrm{X}_{3}\right)\end{array}$} & $\mathrm{X}_{3} .1$ & 0,520 & $r$ hitung $>r$ tabel & Valid \\
\hline & $X_{3} .2$ & 0,609 & $\mathrm{r}$ hitung $>\mathrm{r}$ tabel & Valid \\
\hline & $X_{3} .3$ & 0,568 & $r$ hitung $>r$ tabel & Valid \\
\hline & $X_{3} .4$ & 0,632 & $\mathrm{r}$ hitung $>\mathrm{r}$ tabel & Valid \\
\hline & $X_{3} .5$ & 0,710 & $\mathrm{r}$ hitung $>\mathrm{r}$ tabel & Valid \\
\hline & $X_{3} .6$ & 0,666 & $\mathrm{r}$ hitung $>\mathrm{r}$ tabel & Valid \\
\hline & $X_{3} .7$ & 0,638 & $\mathrm{r}$ hitung $>\mathrm{r}$ tabel & Valid \\
\hline & $\mathrm{X}_{3} .8$ & 0,677 & r hitung $>r$ tabel & Valid \\
\hline \multirow{8}{*}{ Minat Beli (Y) } & Y.1 & 0,584 & $r$ hitung $>r$ tabel & Valid \\
\hline & Y.2 & 0,607 & $r$ hitung $>r$ tabel & Valid \\
\hline & Y.3 & 0,612 & $r$ hitung $>r$ tabel & Valid \\
\hline & Y.4 & 0,517 & $\mathrm{r}$ hitung $>\mathrm{r}$ tabel & Valid \\
\hline & Y.5 & 0,439 & $\mathrm{r}$ hitung $>\mathrm{r}$ tabel & Valid \\
\hline & Y.6 & 0,628 & $\mathrm{r}$ hitung $>\mathrm{r}$ tabel & Valid \\
\hline & Y.7 & 0,628 & $\mathrm{r}$ hitung $>\mathrm{r}$ tabel & Valid \\
\hline & Y.8 & 0,588 & $r$ hitung $>r$ tabel & Valid \\
\hline
\end{tabular}

Sumber: Output SPSS

Berdasarkan hasil uji validitas yang terlihat pada Tabel 1 dapat disimpulkan bahwa seluruh instrument dinyatakan valid karena nilai $r$ hitung lebih besar dari nilai $r$ tabel. Sehingga pengujian dapat dilanjutkan ke pengujian berikutnya.

\section{Hasil Uji Reliabilitas}

Berikut tabel hasil uji reliabilitas menggunakan Cronbach's Alpha:

Tabel 2. Hasil Uji Reliabilitas

\begin{tabular}{|l|c|c|c|}
\hline \multicolumn{1}{|c|}{ Variabel } & $\begin{array}{c}\text { Cronbach Alpha } \\
\text { Hitung }\end{array}$ & $\begin{array}{c}\text { Batas Minimal } \\
\text { Cronbach Alpha }\end{array}$ & Keterangan \\
\hline Harga $\left(\mathrm{X}_{1}\right)$ & 0,749 & 0,70 & Reliabel \\
\hline Promosi $\left(\mathrm{X}_{2}\right)$ & 0,865 & 0,70 & Reliabel \\
\hline Saluran Distribusi $\left(\mathrm{X}_{3}\right)$ & 0,781 & 0,70 & Reliabel \\
\hline Minat beli $(\mathrm{Y})$ & 0,712 & 0,70 & Reliabel \\
\hline
\end{tabular}

Sumber: Output SPSS

Berdasarkan Tabel 2, dapat disimpulkan bahwa semua variabel memiliki nilai cronbach alpha di atas 0,70 dengan demikian dapat dinyatakan bahwa instrumen masing-masing variabel adalah reliabel. Dengan demikian, keseluruhan butir pernyataan kuesioner ini dapat digunakan untuk mengumpulkan data penelitian.

\section{B. Hasil Uji Asumsi Klasik}

\section{Normalitas}

Uji normalitas data menggunakan One-Sample Kolmogorov-Smirnov diperoleh hasil sebagai berikut: 
Website : http://ekomaks.unmermadiun.ac.id/index.php/ekomaks

Tabel 3. Hasil Uji Normalitas Data

One-Sample Kolmogorov-Smirnov Test

\begin{tabular}{|c|c|c|}
\hline & & $\begin{array}{c}\text { Unstandardized } \\
\text { Residual }\end{array}$ \\
\hline$N$ & & 102 \\
\hline Normal Parameters ${ }^{a, b}$ & Mean & 0,0000000 \\
\hline & Std. Deviation & 0,27871760 \\
\hline Most Extreme Differences & Absolute & 0,076 \\
\hline & Positive & 0,076 \\
\hline & Negative & $-0,056$ \\
\hline Test Statistic & & 0,076 \\
\hline Asymp. Sig. (2-tailed) & & $0,156^{\mathrm{e}}$ \\
\hline \multicolumn{3}{|c|}{ a. Test distribution is Normal. } \\
\hline \multicolumn{3}{|c|}{ b. Calculated from data. } \\
\hline \multicolumn{3}{|c|}{ c. Lilliefors Significance Correction. } \\
\hline Sumber: Data prim & olah, 2020 & \\
\hline
\end{tabular}

Menurut Tabel 3, diperoleh nilai sig. 0,156 > 0,05, yang artinya data tersebut berdistribusi normal. Dengan demikian, data tentang harga, promosi, saluran distribusi dan minat beli terdistribusi normal.

2 Multikolinieritas

Apabila nilai tolerance lebih dari 10\% atau 0,1 dan VIF kurang dari 10 maka tidak terjadi multikolinieritas. Hasil uji multikolinieritas adalah sebagai berikut:

Tabel 4. Hasil Uji Multikolinieritas

\begin{tabular}{|l|c|c|}
\hline \multicolumn{1}{|c|}{$\begin{array}{c}\text { Variabel Bebas } \\
\text { Penelitian }\end{array}$} & Tolerance & $\begin{array}{c}\text { Variance Inflation } \\
\text { Factor }(\text { VIF })\end{array}$ \\
\hline Harga $\left(\mathrm{X}_{1}\right)$ & 0,888 & 1,126 \\
\hline Promosi $\left(\mathrm{X}_{2}\right)$ & 0,777 & 1,287 \\
\hline Saluran distribusi $\left(\mathrm{X}_{3}\right)$ & 0,700 & 1,429 \\
\hline
\end{tabular}

Sumber: Output SPSS

Berdasarkan data pada Tabel 4, dapat diketahui bahwa nilai tolerance ketiga variabel bebas lebih besar dari 0,1 dan nilai VIF ketiga variabel bebas kurang dari 10. Artinya, diantara variabel bebas tidak terjadi multikolinieritas.

3 Heterokedastisitas

Hasil uji heteroskedastisitas menggunakan program SPSS adalah sebagai berikut:

Scatterplot

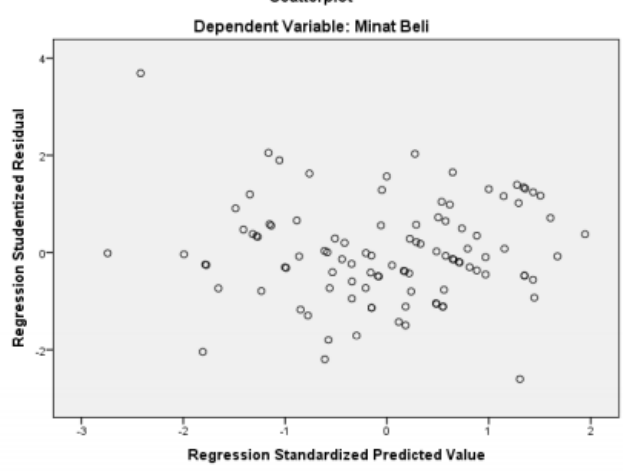

Sumber: Data primer diolah, 2020

Gambar 3. Hasil Uji Heterokedastisitas dengan Scatterplot

Berdasarkan Gambar 3, dapat dilihat bahwa plot atau titik-titik tidak membentuk pola yang jelas serta menyebar di atas dan bawah angka 0 pada sumbu Y. Hal ini menunjukkan bahwa tidak terjadi heteroskedastisitas. Dengan demikian, data yang digunakan dalam penelitian ini telah memenuhi syarat uji heteroskedastisitas.

\section{Hasil Uji Koefisien Determinasi}

Berikut ini hasil uji koefisien determinasi $\left(\mathrm{R}^{2}\right)$ dengan bantuan program SPSS: 
Tabel 5. Hasil Koefisien Determinasi $\left(\mathrm{R}^{2}\right)$

\begin{tabular}{|c|c|r|r|c|}
\hline Model & $\mathrm{R}$ & $\mathrm{R}$ Square & $\begin{array}{c}\text { Adjusted R } \\
\text { Square }\end{array}$ & $\begin{array}{c}\text { Std. Error of the } \\
\text { Estimate }\end{array}$ \\
\hline 1 & $0,703^{\mathrm{n}}$ & 0,495 & 0,479 & 0,2830 \\
\hline
\end{tabular}

a. Predictors: (Constant) Saluran Distribusi, Harga, Promosi

b. Dependent Variable: Minat beli

Sumber: Data primer diolah, 2020

Berdasarkan Tabel 5, diketahui besarnya Adjusted $R$ Square adalah 0,479 atau 47,9\% yang berarti 47,9\% minat beli konsumen pada produk Semen Gresik di PT Abadi Putera Wirajaya Madiun dapat dijelaskan oleh variabel harga, promosi dan saluran distribusi, sedangkan sisanya, yaitu sebesar 52,1\% dijelaskan oleh variabel-variabel lain di luar penelitian, misalnya: kualitas produk, brand awareness dan pengetahuan konsumen tentang produk.

\section{Hasil Uji Hipotesis}

Berikut tabel hasil uji regresi linier berganda:

Tabel 6. Hasil Uji Regresi Linier Berganda

\begin{tabular}{|l|c|r|r|r|l|}
\hline \multirow{2}{*}{ Model } & \multicolumn{1}{|c|}{$\begin{array}{c}\text { Cnstandardized } \\
\text { Coefficients }\end{array}$} & $\begin{array}{c}\text { Standardized } \\
\text { Coefficients }\end{array}$ & & \\
\cline { 2 - 4 } & B & Std. Error & Beta & t & \multirow{2}{*}{ Sig. } \\
\hline 1 (Constant) & 1,131 & 0,320 & & 3,532 & 0,001 \\
Harga & 0,280 & 0,066 & 0,326 & 4,274 & 0,000 \\
Promosi & 0,234 & 0,052 & 0,368 & 4,510 & 0,000 \\
Saluran distribusi & 0,213 & 0,066 & 0,278 & 3,239 & 0,002 \\
\hline
\end{tabular}

a.Dependent Variable: Minat Beli

Sumber: Data primer diolah, 2020

Hasil uji regresi linier berganda pada Tabel 6, dapat diformulasikan persamaannya sebagai berikut:

$\mathrm{Y}=\mathrm{a}+\mathrm{b}_{1} \mathrm{X}_{1}+\mathrm{b}_{2} \mathrm{X}_{2}+\mathrm{b}_{3} \mathrm{X}_{3}+\mathrm{e}$

$\mathrm{Y}=1,131+0,280 \mathrm{X}_{1}+0,234 \mathrm{X}_{2}+0,213 \mathrm{X}_{3}+\mathrm{e}$

4 Uji $t$

Kriteria uji $\mathrm{t}$ adalah jika $-\mathrm{t}_{\text {tabel }} \leq \mathrm{t}_{\text {hitung }} \leq+\mathrm{t}_{\text {tabel }}$ maka Ho diterima (tidak berpengaruh), dan jika $\mathrm{t}_{\text {hitung }}>\mathrm{t}_{\text {tabel }}$ atau - $\mathrm{t}_{\text {hitung }}<-$ $\mathrm{t}_{\text {tabel }}$ maka Ho ditolak (Ha diterima, berpengaruh). Berikut tabel ringkasan hasil uji t pada penelitian ini:

\begin{tabular}{|c|c|c|c|c|c|c|}
\hline Variabel & $\begin{array}{l}\text { Nilai } \\
\mathbf{t}_{\text {hitung }}\end{array}$ & $\begin{array}{c}\text { Hasil } \\
\text { Perbandingan } \\
\left(\text { Nilai }_{\text {tabel }}=\right. \\
\text { 1,98447) }\end{array}$ & Keterangan & $\begin{array}{c}\text { Nilai } \\
\text { Signifikansi }\end{array}$ & $\begin{array}{c}\text { Hasil Perbandingan } \\
\text { (Level of Significant } \\
\text { Penelitian }=0,05)\end{array}$ & Keterangan \\
\hline Harga $\left(X_{1}\right)$ & 4,274 & $>$ thitung & Berpengaruh & 0,000 & $<0,05$ & Signifikan \\
\hline Promosi $\left(\mathrm{X}_{2}\right)$ & 4,510 & $>$ thitung & Berpengaruh & 0,000 & $<0,05$ & Signifikan \\
\hline $\begin{array}{l}\text { Saluran } \\
\text { Distribusi }\left(\mathrm{X}_{3}\right)\end{array}$ & 3,239 & $>$ thitung & Berpengaruh & 0,002 & $<0,05$ & Signifikan \\
\hline
\end{tabular}

Sumber: Output SPSS diolah, 2020

Berdasarkan Tabel 7, dapat disimpulkan bahwa hipotesis yang berbunyi:

a) Harga pada produk Semen Gresik berpengaruh terhadap minat beli konsumen distributor PT Abadi Putera Wirajaya Karesidenan Madiun, diterima.

b) Promosi produk Semen Gresik berpengaruh terhadap minat beli konsumen distributor PT Abadi Putera Wirajaya Karesidenan Madiun, diterima.

c) Saluran distribusi produk Semen Gresik berpengaruh terhadap minat beli konsumen pada distributor PT Abadi Putera Wirajaya Karesidenan Madiun, diterima.

5 Uji F

Tabel 8. Hasil Uji F

\begin{tabular}{|c|c|c|c|c|c|}
\hline \multicolumn{6}{|c|}{ ANOVA $^{\mathrm{a}}$} \\
\hline Model & $\begin{array}{l}\text { Sum of } \\
\text { Squares }\end{array}$ & df & Mean Square & $\mathrm{F}$ & Sig. \\
\hline $\begin{array}{ll}1 & \text { Regression } \\
& \text { Residual } \\
& \text { Total }\end{array}$ & $\begin{array}{r}7,679 \\
7,846 \\
15,525\end{array}$ & $\begin{array}{r}3 \\
98 \\
101\end{array}$ & $\begin{array}{l}2,560 \\
0,080\end{array}$ & 31,972 & $0,000^{\mathrm{b}}$ \\
\hline
\end{tabular}

a.Dependent Variable: Minat beli

b.Predictors: (Constant) Saluran Distribusi, Harga, Promosi

Sumber: Data primer diolah, 2020 
Website : http://ekomaks.unmermadiun.ac.id/index.php/ekomaks

Nilai $F_{\text {tabel }}$ pada penelitian ini sebesar 2,70. Sehingga nilai $F_{\text {hitung }}(31,972)$ lebih besar dari nilai $F_{\text {tabel }}$. Dan nilai signifikansi sebesar 0,000, ini menunjukkan nilainya lebih kecil dari nilai alpha 0,05. Dapat disimpulkan bahwa hipotesis yang berbunyi "Harga, promosi dan saluran distribusi secara simultan berpengaruh terhadap minat beli konsumen pada produk Semen Gresik di distributor PT Abadi Putera Wirajaya Karesidenan Madiun” diterima.

Berdasarkan nilai standardized coefficients yang ditunjukkan pada Tabel 6, diketahui bahwa nilai koefisien beta untuk variabel harga sebesar 0,326, variabel promosi sebesar 0,368 dan variabel saluran distribusi sebesar 0,278. Berdasarkan nilai standardized coefficients beta pada ketiga variabel bebas tersebut maka nilai standardized coefficients beta variabel promosi paling besar dibandingkan nilai standardized coefficients beta pada variabel harga dan saluran distribusi. Dengan demikian, dapat disimpulkan bahwa variabel promosi merupakan variabel yang berpengaruh dominan terhadap minat beli konsumen pada produk Semen Gresik di distributor PT Abadi Putera Wirajaya Karesidenan Madiun

\section{E. Pembahasan}

1 Harga pada produk Semen Gresik berpengaruh terhadap minat beli konsumen distributor PT Abadi Putera Wirajaya Karesidenan Madiun, diterima.

Hasil pada penelitian ini mendukung temuan penelitian yang dilakukan Ati, dkk (2020) yang membuktikan bahwa harga memiliki pengaruh signifikan terhadap minat beli konsumen. Berkaitan dengan pemenuhan atas kebutuhan, konsumen akan memiliki prinsip ekonomi, yaitu akan lebih tertarik dengan produk yang memiliki harga yang rendah. Ketepatan PT Semen Indonesia, Tbk. dalam menetapkan harga, khususnya harga eceran tertinggi, yang ditindaklanjuti PT Abadi Putera Wirajaya Madiun sebagai distributor produk Semen Gresik dalam menetapkan harga semen yang dijual langsung kepada konsumen, akan membuat minat beli konsumen meningkat. Penetapan harga semen yang sesuai dengan keinginan konsumen, akan menjadi rangsangan atau stimulus bagi konsumen untuk berminat melakukan pembelian semen di PT Abadi Putera Wirajaya Madiun.

Banyak hal yang berkaitan dengan harga yang melatarbelakangi mengapa konsumen memilih suatu produk untuk dimilikinya, konsumen memilih suatu produk tersebut. Misalnya, karena ingin benar-benar ingin merasakan nilai dan manfaat dari produk tersebut atau karena melihat kesempatan memiliki produk tersebut dengan harga yang lebih murah biasanya sehingga lebih ekonomis. Harga yang baik dapat menjadi tolak ukur perusahaan dalam menciptakan minat beli konsumen yang maksimal. Harga yang baik adalah yang memenuhi beberapa kriteria, seperti: harga yang terjangkau oleh konsumen, kesesuaian harga dengan kualitas produk, kesesuaian harga dengan manfaat yang diinginkan konsumen serta adanya anggapan bahwa harga sesuai kemampuan atau daya saing harga dengan di tempat lain.

Berdasarkan hasil kuesioner, diketahui bahwa terdapat beberapa hal yang menyebabkan harga berpengaruh terhadap minat pembelian. Jika harga grosir Semen Gresik yang dijual di PT Abadi Putera Wirajaya sesuai dengan keinginan konsumen, maka akan dapat meningkatkan minat pembelian. Selain itu, menurut para pemilik toko dan distributor, PT Abadi Putera Wirajaya Madiun menjual Semen Gresik dengan harga lebih murah daripada di tempat lain. Harga Semen Gresik yang dijual di PT Abadi Putera Wirajaya Madiun sesuai kualitas yang konsumen harapkan serta rata-rata adalah barang baru sehingga jarang ada yang sudah mengeras. Menurut responden, membeli Semen Gresik di PT Abadi Putera Wirajaya Madiun tidak dikenai biaya pengiriman dan dilakukan dengan cepat sehingga produk dapat segera digunakan. Jika membeli membeli Semen Gresik di PT Abadi Putera Wirajaya Madiun dalam jumlah yang banyak, akan mendapat potongan harga yang semakin besar. Harga Semen Gresik yang dijual di PT Abadi Putera Wirajaya Madiun juga dianggap menguntungkan untuk dijual kembali. Beberapa pendapat konsumen tentang harga di atas menyebabkan minat beli konsumen terhadap produk Semen Gresik di PT Abadi Putera Wirajaya Madiun akan meningkat.

2 Promosi produk Semen Gresik berpengaruh terhadap minat beli konsumen distributor PT Abadi Putera Wirajaya Karesidenan Madiun, diterima.

Hasil pada penelitian ini mendukung temuan penelitian yang dilakukan Hastono \& Triyadi (2020) bahwa promosi berpengaruh signifikan terhadap minat konsumen. Promosi yang dilakukan PT Abadi Putera Wirajaya Madiun akan dapat menjadi sumber informasi bagi masyarakat tentang keberadaan Semen Gresik. Berkaitan dengan promosi, maka dapat diketahui dari sejauhmana periklanan tentang produk Semen Gresik yang disampaikan perusahaan, kegiatan penjualan personal dan promosi penjualan Semen Gresik yang diterapkan PT Abadi Putera Wirajaya Madiun, informasi dari mulut ke mulut pada konsumen tentang Semen Gresik yang dijual di PT Abadi Putera Wirajaya Madiun serta adanya pemasaran langsung Semen Gresik di PT Abadi Putera Wirajaya Madiun.

Berkaitan dengan promosi, maka menurut hasil kuesioner bahwa iklan produk dan harga yang disampaikan di pamflet, brosur, dan spanduk pada PT Abadi Putera Wirajaya Madiun menarik. Selain itu, melalui promosi yang dilakukannya, PT Abadi Putera Wirajaya Madiun rutin menginformasikan tentang diskon dan harga Semen Gresik melalui iklan dalam brosur terlihat jelas. Karyawan PT Abadi Putera Wirajaya Madiun juga memberikan informasi yang jelas tentang kebijakan penetapan harga eceran tertinggi dan produk Semen Gresik dengan baik. Menurut responden, pembelian Semen Gresik di PT Abadi Putera Wirajaya Madiun menguntungkan karena adanya program-program promosi berupa bonus pembelian serta adanya potongan harga tertinggi yang lebih menarik dibandingkan di tempat lain. 
Website : http://ekomaks.unmermadiun.ac.id/index.php/ekomaks

3 Saluran distribusi produk Semen Gresik berpengaruh terhadap minat beli konsumen pada distributor PT Abadi Putera Wirajaya Karesidenan Madiun, diterima.

Hasil penelitian ini mendukung penelitian yang dilakukan Sukma, dkk (2020) bahwa distribusi berpengaruh signifikan terhadap minat beli produk. Keberhasilan PT Semen Indonesia, Tbk dalam meningkatkan minat pembelian konsumen terhadap produk Semen Gresik juga tidak terlepas dari keberhasilan perusahaan dalam menentukan saluran distribusi yang digunakan dalam menjual produk. PT Abadi Putera Wirajaya Madiun merupakan salah satu distributor dari PT Semen Indonesia, Tbk dan sebagai salah satu saluran pemasaran atau distribusi dalam penjualan produk Semen Gresik kepada konsumen. Ketepatan dalam memilih saluran distribusi akan menentukan keberhasilan dan kegagalan usaha di masa yang akan datang. Apabila distribusi produk ke pasar sangat lancar, maka produk akan mudah dijangkau dan tersedia bagi pasar sasaran. Keberadaan PT Abadi Putera Wirajaya Madiun sebagai salah satu distributor dari produk Semen Gresik serta toko-toko dari sub-distributor akan membantu pendistribusian produk Semen Gresik ke masyarakat sebagai konsumen dengan tepat sasaran. Apabila konsumen dapat menjangkau keberadaan produk dengan mudah serta ketersedian produk di pasar sangat mudah ditemukan, konsumen akan memiliki minat pembelian yang tinggi terhadap produk.

Adanya pengaruh saluran distribusi terhadap minat beli konsumen pada produk Semen Gresik di PT Abadi Putera Wirajaya Madiun dapat dilihat dari hasil kuesioner. Menurut responden, dapat diketahui bahwa PT Abadi Putera Wirajaya Madiun memiliki tempat penyimpanan yang luas dan tempat bertransaksi yang nyaman dan lokasinya mudah diakses. Di PT Abadi Putera Wirajaya, ketersediaan Semen Gresik selalu tepat waktu. PT Abadi Putera Wirajaya Madiun cepat merespon ketika konsumen menanyakan tentang ketersediaan produk. Bentuk dan ukuran Semen Gresik yang ada di PT Abadi Putera Wirajaya memiliki kesamaan sehingga pendistribusiannya mudah dilakukan. Pendistribusian Semen Gresik dari PT Abadi Putera Wirajaya Madiun melalui armada pengiriman dari perusahaan tanpa dikenai tambahan biaya pengiriman. Adanya pendapat responden tentang hal-hal yang berkaitan dengan distribusi tersebut, maka akan mempengaruhi minat para pemilik toko dan distributor untuk melakukan pembelian produk Semen Gresik di PT Abadi Putera Wirajaya Madiun.

4 Harga, promosi dan saluran distribusi secara simultan berpengaruh terhadap minat beli konsumen pada produk Semen Gresik di distributor PT Abadi Putera Wirajaya Karesidenan Madiun

Hasil penelitian ini relevan dengan temuan penelitian yang dilakukan Abda \& Sutrisna (2018) bahwa variabel harga, promosi, dan distribusi secara simultan berpengaruh terhadap minat beli konsumen. Keberadaan minat pembelian tidak terlepas dari perilaku konsumen dalam merespon positif terhadap hal-hal yang telah disampaikan para pemasar dan berminat untuk melakukan pembelian suatu produk. Hal ini seperti yang disampaikan Kotler \& Keller (2016) bahwa minat beli konsumen adalah "Sebuah perilaku konsumen dimana konsumen mempunyai keinginan dalam membeli atau memilih suatu produk, berdasarkan pengalaman dalam memilih, menggunakan dan mengkonsumsi atau bahkan menginginkan suatu produk." Pada konsumen yang mempunyai minat untuk membeli suatu produk menunjukkan adanya perhatian dan rasa senang terhadap produk untuk kemudian minat membeli tersebut akan diikuti dengan realisasi yang berupa perilaku membeli. Keberadaan minat pembelian pada konsumen tidak terlepas dari kemampuan perusahaan dalam mengetahui perilaku konsumen. Beberapa faktor yang diduga dapat menjadi stimulus seorang konsumen berminat untuk melakukan pembelian terhadap suatu produk adalah harga dan promosi yang diterapkan pemasar serta saluran distribusi yang digunakan pemasar untuk menjual produk di pasar.

Minat beli konsumen pada produk Semen Gresik di distributor PT Abadi Putera Wirajaya Karesidenan Madiun tidak terlepas dari berbagai hal. Menurut hasil kuesioner diketahui bahwa penetapan harga jual kembali yang menguntungkan di PT Abadi Putera Wirajaya membuat toko/distributor selalu ingin membeli di tempat tersebut. Saat keluar program promosi harga dari produk Semen Gresik, toko/distributor menyempatkan untuk mencari informasidi PT Abadi Putera Wirajaya. Dibandingkan wholesaler lain, PT Abadi Putera Wirajaya memberikan kemudahan bagi konsumen sehingga saat ingin membeli Semen Gresik, toko/distributor selalu memilih membeli di tempat ini. Petugas penjualan dan pramuniaga PT Abadi Putera Wirajaya memberikan penjelasan tentang berbagai karakteristik Semen Gresik dengan baik, sehingga wholesaler ini merupakan pilihan terbaik bagi toko/distributor untuk melakukan pembelian.

5 Variabel yang Berpengaruh Dominan terhadap Minat Beli Produk Semen Gresik di Distributor PT Abadi Putera Wirajaya Karesidenan Madiun

Hasil penelitian ini relevan dengan temuan penelitian yang dilakukan Ati, dkk (2020) bahwa variable yang paling dominan mempengaruhi minat beli konsumen adalah variabel promosi. Promosi merupakan salah satu kegiatan pemasaran yang penting bagi perusahaan dalam upaya mempertahankan kelangsungan hidup perusahaan serta meningkatkan kualitas penjualan untuk meningkatkan kegiatan pemasaran dalam hal memasarkan barang atau jasa dari suatu perusahaan. Promosi merupakan salah satu cara bagi PT Semen Indonesia, Tbk. dan PT Abadi Putera Wirajaya Madiun dalam memperkenalkan produk, khususnya produk Semen Gresik. Promosi ini dapat dilakukan dengan berbagai cara, baik cetak maupun elektronik. Apabila PT Semen Indonesia, Tbk dan PT Abadi Putera Wirajaya Madiun mampu memilih strategi promosi penjualan dengan media promosi yang tepat, akan membuat produk Semen Gresik semakin 
Website : http://ekomaks.unmermadiun.ac.id/index.php/ekomaks

dikenal konsumen. Apabila konsumen telah mengenal dengan baik produk Semen Gresik, maka akan mendorong konsumen untuk tertarik membeli produk Semen Gresik.

\section{KESIMPULAN DAN SARAN}

\section{A. Kesimpulan}

Harga, promosi, dan saluran distribusi berpengaruh terhadap minat beli konsumen produk Semen Gresik di distributor PT Abadi Putera Wirajaya Karesidenan Madiun. Variabel-variabel ini penting untuk dapat diperhatikan oleh PT Semen Indonesia, Tbk dan distributor ini. Harga murah tapi berkualitas merupakan kepuasan bagi konsumen dalam membeli produk tersebut. Promosi yang jelas dan media promosi yang dipakai semakin membuat konsumen dan calon konsumen tertarik. Tempat saluran distribusi yang nyaman bagi konsumen akan membuat konsumen semakin betah untuk melakukan transaksi dengan saluran distribusi tersebut. Sehingga daya beli konsumen terhadap produk Semen Gresik akan menjadi meningkat.

\section{B. Saran}

Berdasarkan hasil penelitian dapat disampaikan beberapa saran kepada PT Abadi Putera Wirajaya Madiun, yaitu:

1. Perusahaan secara konsisten agar tetap membebaskan biaya pengiriman produk Semen Gresik yang dibeli konsumen serta memberikan potongan harga dengan berbagai besaran, sesuai dengan jumlah pembelian yang dilakukan konsumen.

2. PT Abadi Putera Wirajaya Madiun disarankan untuk lebih meningkatkan lagi frekuensi dan intensitas promosi yang dilakukannya agar dapat menarik minat beli pada konsumen.

3. PT Abadi Putera Wirajaya Madiun sebaiknya terus meningkatkan kelancaran pendistribusian produk Semen Gresik, terutama pada ketepatan waktu pendistribusian. Hal ini perlu dilakukan agar ketersediaan Semen Gresik di pasar selalu tepat waktu, sehingga tidak menyebabkan konsumen berpindah ke merek semen lain atau distributor Semen Gresik yang lain.

Saran untuk penelitian selanjutnya adalah mengembangkan penelitian ini dengan menambahkan variable-variabel lain yang berkaitan dengan minat beli konsumen. Seperti kualitas produk, brand awareness, pengetahuan konsumen tentang produk, dan lain sebagainya.

\section{VI.DAFTAR PUSTAKA}

Abda, N., \& Sutrisna, E. (2018). Pengaruh Kualitas Produk, Harga, Promosi dan Distribusi Terhadap Minat Beli Konsumen Toko Vizcake Pekanbaru. JOM FISIP, 5(II), 1-15. Retrieved Desember 6, 2020, from https://jom.unri.ac.id/index.php/JOMFSIP/article/view/21039

Alma, B. (2013). Manajemen Pemasaran dan Pemasaran Jasa. Bandung: Alfabeta.

ASI. (2019). Konsumen Semen Domestik Indonesia. Retrieved Desember 6, 2020, from Asosiasi Semen Indonesia: https://asi.or.id/konsumsi_semen_domestik_indonesia.html

Ati, P. S., Islamudin, \& Finthariasari, M. (2020). Pengaruh Promosi, Harga dan Kualitas Produk Terhadap Minat Beli Konsumen Produk Elektronik Merek Polytron. Jurnal Entrepreneur dan Manajemen Sains (JIEMS), 1(2). Retrieved Desember 6, 2020, from https://jurnal.umb.ac.id/index.php/jems/article/view/921

Ghozali, I. (2016). Aplikasi Analisis Multivariate Dengan Program IBM SPSS 23. Semarang: Badan Penerbit Universitas Diponegoro.

Hastono, H., \& Triyadi. (2020). Pengaruh Harga dan Promosi terhadap Minat Beli. Jurnal Ekonomi Efektif, 2(3), 372-379. Retrieved 12 6, 2020, from http://openjournal..unpam.ac.id/index.php/JEE/article/view/6800

Kotler, P., \& Amstrong, G. (2016). Principle of Marketing. New Jersey: Pearson prentice Hall, Inc.

Kotler, P., \& Keller, K. L. (2016). Marketing Management (15 ed.). New Jersey: Pearson Prentice Hall, Inc.

Lupiyoadi, R., \& Hamdani. (2013). Manajemen Pemasaran Jasa. Jakarta: Salemba Empat.

Mahmoud, T. O. (2018). Impact of Green Marketing Mix on Purchase Intention. International Journal of Advanced and Applied Sciences, 5(2), 127-135. Retrieved Desember 12, 2020, from https://www.researchgate.net/publication/322865212_Impact_of_green_marketing_mix_on_purchase_intention

Saleh, M. Y., \& Said, M. (2019). Konsep dan Strategi Pemasaran. Makassar: CV Sah Media.

Sukma, A., Hermina, N., \& Novan, D. (2020). Pengaruh Produk, Distribusi dan Digital marketing terhadap Minat beli Produk UMKM Binaan Kadin Jabar Pada Situasi Covid-19. MANNERS Management and Entrepreneurship Journal, 3(2), 91-102. Retrieved Desember 6, 2020, from http://jurnal.unnur.ac.id/index.php/manners/article/view/355

Suparyanto, R. W., \& Rosad. (2015). Manajemen Pemasaran. Surabaya: In Media.

Tjiptono, F. (2015). Strategi Pemasaran. Yogyakarta: ANDI. 